\title{
Water Consumption in the City of Rzeszow
}

\author{
Janusz Rak, Katarzyna Pietrucha, Monika Solecka \\ Technical University of Rzeszow \\ Civil and Environmental Engineering Faculty, Department of Water Supply and Sewerage Systems \\ e-mail: rakjan@prz.edu.pl,kpiet@prz.edu.pl
}

\begin{abstract}
The aim of the work is the analysis of water consumption in Rzeszow city. The quantity of produced water in Water Plants: Zwieczyca I and Zwieczyca II were performed for years $2007 \div 2009$. The individual average twenty-four hour water consumption per one inhabitant was estimated. A stable decrease was observed in annual water consumption in years $2000 \div 2009$. On the example of housing estate Nowe Miasto, the analysis of water consumption concerning the heights of the buildings was made. The biggest individual water consumption was marked in ten-storey house, and the smallest in single-family house. The next step regard the water consumption depending on the days in week. The biggest water consumption was in Thursdays, and the smallest in Sundays. Also the maximum and minimum twenty-four hour water consumption in the division into months in 2009 year were determined.
\end{abstract}

Key words: water supply, water consumption

\section{Introduction}

In Rzeszow water pipes form a vast and dense network, working at $80 \%$ in the ring. Thanks to it, greater efficiency of the entire distribution system is ensured. Pipes spread beyond the city limits, supplying water to the adjacent municipalities of Boguchwała, Głogów Młp , Krasne, Tyczyn, Swilcza, but these places are less than $8 \%$ of the total sale of water $[1,2,7,8]$.

The water supply network consists of five water mains, which transport water from the intakes in the direction of the expansion tanks. Simultaneously, the area of the city is powered from numerous branches:

- The water main "Rzeszów" (Ф315) is the oldest main in the city (the 1934 cast iron). It supplies water to the residents of Hetmańska Street, 3 May Street and Krakowska Street.

- The water main “0” ( $\Phi 1200, \Phi 1000, \Phi 800)$ is the newest and largest main in Rzeszów. It brings water from the water treatment plant Zwięczyca II to the north - west part of the city and to the tanks in Baranówka. 
- The water main "1"(Ф400) transports water from the water treatment plant Zwięczyca I to the centre and to the northern area of the city. This pipeline has two branches, one of which feeds Boguchwała and Mogielnica, and the other one Zwięczyca, Racławówka and Niechobrz.

- The water main "2" (Ф400) transports water from the water treatment plant Zwięczyca I to the south and central part of the city.

- The water main “3”( $(\Phi 400)$ is used to transport water from the water treatment plants Zwięczyca I and II to the east and north - eastern area of the city. It powers the tanks in Pobitno. At the initial section of the water main there are two branches, $\Phi 150$ and $\Phi 100$, which supply water to the districts Budziwój and Biała.

Thanks to such layout of water mains there is the possibility to control water flow to various parts of the city, using the available pressure in the pumping station. The largest amount of water flows by the water mains " 0 ", " 1 " and " 2 ", powering a left-bank part of the city. They cooperate with the tanks in Baranówka. The right- bank part of the city is powered by the water main " 3 ", which cooperates with the tanks in Pobitno. Both parts of the city are connected by three pipelines $(\Phi 400)$, which run along the bridge on the Wisłok river.

\section{The quantity of water produced and treated in Zwięczyca}

\subsection{Water treatment plant I}

Table 1 shows the production of water in the water treatment plant I in the years 2007-2009. Data from 2007 are lower than in subsequent years because from April to December the plant was shut down due to modernization. At that period of time water was produced only in the water treatment plant II.

Table 1: The quantity of water produced in the water treatment plant I in the years 2007-2009

\begin{tabular}{|c|c|c|}
\hline \multirow{2}{*}{ Year } & \multicolumn{2}{|c|}{ The quantity of water } \\
\cline { 2 - 3 } & {$\left[\mathrm{m}^{3} /\right.$ year $]$} & {$\left[\mathrm{m}^{3} /\right.$ year $]$} \\
\hline 2007 & 1966743 & 5388 \\
2008 & 6284090 & 17217 \\
2009 & 5970434 & 16357 \\
\hline
\end{tabular}

\subsection{Water treatment plant II}

Table 2 contains data on the production of water by the water treatment plant II in the years 2007-2009. The production of water in the water treatment plant II in 2007 is, as in the water treatment plant I, not typical, because the water treatment plant I was then modernized. 
Table 2: The quantity of water produced in the water treatment plant II in the years 2007-2009

\begin{tabular}{|c|c|c|}
\hline \multirow{2}{*}{ Year } & \multicolumn{2}{|c|}{ The quantity of water } \\
\cline { 2 - 3 } & {$\left[\mathrm{m}^{3} /\right.$ year $]$} & {$\left[\mathrm{m}^{3} /\right.$ year $]$} \\
\hline 2007 & 10912819 & 29898 \\
\hline 2008 & 6682912 & 18309 \\
2009 & 6569113 & 17998 \\
\hline
\end{tabular}

\section{Analysis of water consumption}

\subsection{Unit water consumption}

The basic parameter for calculating water consumption is unit water consumption indicator $\left(\mathrm{m}^{3} / \mathrm{Md}\right)$. This is the ratio of daily water consumption $\left(\mathrm{Q}_{\mathrm{d}}\right)$ to the number of inhabitants. Table 3 presents the decline in unit water consumption in the past three years.

Table 3: Unit water consumption of Rzeszow

\begin{tabular}{|c|c|c|c|c|}
\hline \multirow{2}{*}{ Year } & \multirow{2}{*}{$\begin{array}{c}\text { The number } \\
\text { of inhabitants }\end{array}$} & \multicolumn{2}{|c|}{ Water consumption } & \multirow{2}{*}{$\begin{array}{c}\text { Unit water } \\
\text { consumption } \\
{\left[\mathrm{m}^{3} / \mathrm{Md}\right]}\end{array}$} \\
\cline { 3 - 4 } & {$\left[\mathrm{m}^{3} \cdot 10^{3}\right]$} & {$\left[\mathrm{m}^{3} / \mathrm{d}\right]$} & \\
\hline 2007 & 170700 & 9709 & 26600 & 0,156 \\
2008 & 172700 & 9479 & 25970 & 0,150 \\
2009 & 177800 & 9409 & 25778 & 0,145 \\
\hline
\end{tabular}

The above table and a graph show that the unit water consumption for one inhabitant per day, in 2007-2009, was from 145 to $156 \mathrm{dm}^{3} / \mathrm{Md}$. Unit water consumption decreases with each passing year (in 2000 it was $191 \mathrm{dm}^{3} / \mathrm{Md}$ ).

\subsection{Water consumption in the city of Rzeszow in the years 2000-2009}

The analysis of water consumption over the years and in particular months was based on information from the Sales Department at Municipal Enterprise for Water and Sewage (MEWS) in Rzeszów. Data refer to the quantity of water sold to customers.

Table 4 shows water consumption in Rzeszów in the past ten years. 
Table 4: Water consumption in the city of Rzeszow in the years 2000-2009

\begin{tabular}{|c|c|c|}
\hline \multirow{2}{*}{ Year } & \multicolumn{2}{|c|}{ Water consumption } \\
\cline { 2 - 3 } & {$\left[\mathrm{m}^{3} /\right.$ year $]$} & {$\left[\mathrm{m}^{3} / \mathrm{d}\right]$} \\
\hline 2000 & 11288000 & 30926 \\
2001 & 10762000 & 29485 \\
2002 & 10418000 & 28542 \\
2003 & 10155000 & 27822 \\
2004 & 9766000 & 26756 \\
2005 & 9603000 & 26310 \\
2006 & 9640000 & 26411 \\
2007 & 9709000 & 26600 \\
\hline 2008 & 9479000 & 25970 \\
2009 & 9409000 & 25778 \\
\hline
\end{tabular}

In the years 2000-2009 there was a decrease of water consumption in Rzeszow by $17 \%$.

The reason is, among others, use of efficient appliances in households and permanent increase in price of $1 \mathrm{~m} 3$ of water. The decrease of water consumption is also caused by reducing water consumption by major industrial users.

It may be noted that after years of a large drop in demand for water, there was a slight increase in water consumption, which may be partly dictated by the connection of new areas to the city (since 2006). It also proves the stabilization of the lower border value of unit water consumption in households in the city.

\subsection{Monthly water consumption in Rzeszow in 2009}

Water consumption in the subsequent months of the year depends on many factors. The important factor is the season of the year. In winter and holidays water consumption is the lowest. When there is drought - water demand is higher (eg for watering plots, gardens), and in rainy period customers use less water. The changing number of residents (students, people leaving on holidays, commuters and seasonal workers) is also important.

Table 5 lists the water consumption in each month in 2009.

Table 5: Monthly water consumption in Rzeszow in 2009

\begin{tabular}{|c|c|c|}
\hline \multirow{2}{*}{ Month } & \multicolumn{2}{|c|}{ Water consumption } \\
\cline { 2 - 3 } & $\mathrm{m}^{3} / \mathrm{month}$ & $\mathrm{m}^{3} / \mathrm{d}$ \\
\hline January & 738046 & 23808 \\
February & 702180 & 25078 \\
\hline
\end{tabular}




\begin{tabular}{|c|l|l|} 
March & 788888 & 25448 \\
April & 822430 & 27414 \\
May & 781247 & 25202 \\
June & 852788 & 28426 \\
July & 787909 & 25416 \\
August & 754428 & 24336 \\
September & 808895 & 26963 \\
October & 814472 & 26273 \\
November & 779820 & 25994 \\
December & 778271 & 25106 \\
\hline
\end{tabular}

The highest daily consumption occurs in June - $28426 \mathrm{~m}^{3} / \mathrm{d}$ and lowest in January - 23808 $\mathrm{m}^{3} / \mathrm{d}$.

\subsection{Water consumption depending on the height of buildings}

The data used in this chapter were obtained from the Housing Cooperative "New Town" in Rzeszów and from the Municipal Enterprise for Water and Sewage. The study involved use of water by the residents of selected buildings and houses in the New Town estate in 2009. Table 6 shows the number of inhabitants and water consumption depending on the height of buildings.

Table 6: Water consumption depending on the height of buildings

\begin{tabular}{|c|c|c|c|c|c|}
\hline \multirow{2}{*}{ No. } & Building & \multirow{2}{*}{$\begin{array}{c}\text { Number of } \\
\text { floors }\end{array}$} & $\begin{array}{c}\text { Number of } \\
\text { inhabitants }\end{array}$ & \multicolumn{2}{|c|}{ Water consumption } \\
\cline { 4 - 6 } & & X & 347 & 16021 & 0,126 \\
\hline 1 & Block & X & 365 & 18432 & 0,138 \\
2 & Block & X & 421 & 20773 & 0,135 \\
3 & Block & IV & 267 & 10855 & 0,111 \\
4 & Block & IV & 471 & 19444 & 0,113 \\
5 & Block & IV & 203 & 8209 & 0,111 \\
6 & Block & III & 26 & 867 & 0,091 \\
7 & Tenement house & III & 46 & 1833 & 0,109 \\
8 & Tenement house & III & 45 & 1585 & 0,096 \\
9 & Tenement house & - & 3 & 84 & 0,077 \\
10 & House & - & 5 & 192 & 0,105 \\
11 & House & - & 4 & 144 & 0,099 \\
12 & House & - & & & \\
\hline
\end{tabular}

Based on the data depicted in a figure, one can observe some dependence between the height of construction and water consumption. The higher the building the higher the demand for water. In ten-storey blocks water consumption is the highest, the lowest demand occurs in the houses. 


\subsection{Water consumption depending on the day of the week}

The great regularity of water consumption can be seen in a weekly cycle. On Monday water consumption is low, then rises and reaches the highest value in the middle of the week. Then water consumption gradually decreases, reaching a minimum value on Sunday. Such a distribution of water consumption is the result of the nature of the city - in the week, people come to work and various investments in the capital of Subcarpatian are carried out.

Table 7 shows water consumption in the ordinary working week, from 18 to 24 May 2009.

Table 7: Water consumption depending on the day of the week

\begin{tabular}{|c|c|}
\hline The day of the week & $\begin{array}{c}\text { Water } \\
\text { consumption } \\
{\left[\mathrm{m}^{3} / \mathrm{d}\right]}\end{array}$ \\
\hline Monday (18.05) & 37652 \\
Tuesday (19.05) & 38089 \\
Wensday (20.05) & 38349 \\
Thursday (21.05) & 39748 \\
\hline Friday (22.05) & 36574 \\
Saturday (23.05) & 34537 \\
Sunday (24.05) & 31358 \\
\hline
\end{tabular}

\subsection{Daily water consumption Qmax and Qmin in 2009}

Table 8 summarizes the highest $\left(\mathrm{Q}_{\max }\right)$ and the lowest $\left(\mathrm{Q}_{\min }\right)$ daily water consumption by the public in particular months in 2009.

Table 8: $\mathrm{Q}_{\max }$ i $\mathrm{Q}_{\min }$ in particular months in 2009

\begin{tabular}{|c|c|c|}
\hline Month & $\mathrm{Q}_{\max }\left[\mathrm{m}^{3} / \mathrm{d}\right]$ & $\mathrm{Q}_{\min }\left[\mathrm{m}^{3} / \mathrm{d}\right]$ \\
\hline January & 41708 (08 - Thursday) & 35315 (02 - Friday) \\
\hline February & 40972 (02 - Monday) & 32564 (09 - Monday) \\
\hline March & 39385 (24 - Tuesday) & 31171 (12 - Thursday) \\
\hline April & 40489 (29 - Wensday) & 23685 (12 - Sunday, Holiday) min \\
\hline May & 42517 (15 - Friday) & 31333 (31 - Sunday) \\
\hline June & 40152 (09 - Tuesday) & 29437 (11 - Thursday, Holiday) \\
\hline July & 43563 (15 - Wensday) & 30775 (12 - Sunday) \\
\hline August & 44213 (05 - Wensday) max & 28292 (16 - Sunday) \\
\hline September & 37986 (02 - Wensday) & 30938 (06 - Sunday) \\
\hline October & 38932 (22 - Thursday) & 34211 (19 - Monday) \\
\hline November & 39237 (20 - Friday) & 30027 (01 - Sunday, Holiday) \\
\hline December & 39350 (02 - Wensday) & 30369 (26 - Saturday, Holiday) \\
\hline
\end{tabular}


The highest daily consumption took place in August (05.08), and the lowest in April.

\subsection{Water price versus inflation}

The analysis was performed assuming that the price for $1 \mathrm{~m}^{3}$ of water in 2000 was $100 \%$. Table 9 presents the formation of water prices, according to MEWS, Rzeszow and inflation, according to Central Statistical Office, in the last decade.

Table 9: Water price versus inflation in Rzeszow in 2000-2009

\begin{tabular}{|c|c|c|c|}
\hline \multirow{2}{*}{ Year } & $\begin{array}{c}\text { The price for } \\
1 \mathrm{~m}^{3} \text { of } \\
\text { water }\end{array}$ & $\begin{array}{c}\text { The } \\
\text { percentage } \\
\text { increase of } \\
\text { water prices }\end{array}$ & Inflation \\
\cline { 2 - 4 }$[\mathrm{zl}]$ & {$[\%]$} & {$[\%]$} \\
\hline 2000 & 1,50 & 100,0 & 100,0 \\
2001 & 1,87 & 124,7 & 105,5 \\
\hline 2002 & 2,04 & 136,0 & 107,4 \\
2003 & 2,08 & 138,7 & 108,2 \\
2004 & 2,12 & 141,3 & 111,7 \\
2005 & 2,17 & 144,7 & 113,8 \\
2006 & 2,18 & 145,3 & 114,8 \\
2007 & 2,22 & 148,0 & 117,3 \\
2008 & 2,35 & 156,7 & 121,5 \\
2009 & 3,16 & 210,7 & 125,0 \\
\hline
\end{tabular}

Over the past ten years the price for $1 \mathrm{~m}^{3}$ of water has grown steadily. The price of water increased by $110,7 \%$ and inflation by $25 \%$. In 2009 , the residents of Rzeszow paid for water two times more than in 2000.

\section{Conclusion}

Analysis of water consumption in Rzeszow showed that water demand throughout the year is uneven and is subject to fluctuations. It is formed by many factors, including climatic conditions, local conditions, holidays, public holidays, lifestyle, accidents, the amount of pressure in the network, failures in the network and equipment failures, etc.

The winter months are characterized by less use of water than the summer months. In 2009, the highest demand for water was in June, the lowest in January. One could also note that the highest water consumption occurred on working days, while the lowest was on Sundays and public holidays. Detailed analysis showed that the highest amount of water per year is consumed by households $(74,29 \%)$ and the lowest by industry $(10,41 \%)$. 
The phenomenon of decreasing consumption of tap water, which occurred during study, can be assessed as positive, because it is associated with a rational water management and saving. Significant positive changes have occurred in the factors that previously caused the waste of water. Better and more modern materials and fittings for installation appear on the market. All of this creates the technical possibilities of reducing or even eliminating water losses due to leakage in residential installations $[3,4,5,6]$.

Apart from technical reasons for reducing water consumption, clearly favourable economic factor - increasing price for $1 \mathrm{~m}^{3}$ of water- also occurred. All this results in rationalization of water consumption, leading consequently to a decline in unit water consumption. The performed analysis shows that population increases and unit water consumption decreases from $156 \mathrm{~m}^{3} / \mathrm{d}$ in 2007 to $145 \mathrm{~m}^{3} / \mathrm{d}$ in 2009 .

\section{References}

[1] Pietrucha, K. (2008). Analiza czasu odnowy i naprawy podsystemu dystrybucji wody dla miasta Rzeszowa. Instal. Volume 10, pp. 113-115.

[2] Rak, J., Studziński, A. (2005). The Chosen Problems of Rzeszów Water Supply System Exploitation. In 10th Scientific Conference Rzeszów-Lviv-Kosice, State of Art, Trends of Development and Challenges in Civil Enginering, 2005 (pp. 328-335). Kosice: Technical University of Kosice.

[3] Rak, J., Tchórzewska-Cieślak, B. (2007). Analiza zużycia wody przez mieszkańców Dębicy. Zeszyty Naukowe Politechniki Rzeszowskiej Budownictwo i Inżynieria Środowiska.Volume 42, pp. 113-122.

[4] Rak, J., Tchórzewska-Cieślak, B. (2000). Analiza zużycia wody do picia w mieście Rzeszowie. Mat. konf. IV Miedzynarodowej Konfenfrencji, XVI Krajowa Konferencja nt. Zaopatrzenie jakość i ochrona wód, 2000 (pp. 927-933). Kraków-Poznań.

[5] Rak, J., Tchórzewska-Cieślak, B. (2001). Analiza zużycia wody do spożycia w wybranych osiedlach miasta Rzeszowa. In Mat. konf. Konferencji Naukowo-Szkoleniowej, nt. Problemy budownictwa wodnego i gospodarki wodno-ściekowej w Polsce ze szczególnym uwzględnieniem regionu Podkarpacia, Myczkowce 2001 (pp. 236-240). Rzeszów: Wydawnictwo RZECH-DRUK.

[6] Rak, J., Tchórzewska-Cieślak, B. (2001). Zużycie wody do spożycia w mieście Rzeszowie z uwzględnieniem wysokości zabudowy. In Mat. konf. VI Międzynarodowej Konferencji Naukowej Rzeszów-Lwów-Koszyce, 2001 (pp. 6-13). Lwów: Wydawnictwo Politechnika Lwowska.

[7] Kwietniewski, M., Rak, J. (2009). Niezawodność infrastruktury wodociagowej i kanalizacyjnej w Polsce - stan badań i możliwości jej poprawy. Warszawa: Komitet Inżynierii Lądowej i Wodnej PAN.

[8] Solecka, M. (2010). Zużycie wody w mieście Rzeszowie. Praca dyplomowa magisterska, Politechnika Rzeszowska. 